\title{
A música para crianças da dupla Palavra Cantada
}

Paulo Tatit e Sandra Peres formam a dupla Palavra Cantada. Eles têm dez anos de carreira, conquistaram um espaço para a música infantil de qualidade e consolidaram um selo independente com um portfólio composto pelos já clássicos: Canções de ninar, Canções de brincar, Cantigas de roda,

Canções curiosas, Meu neném, Canções do Brasil, Pé com pé, entre outros.

Trabalho inovador no cenário da música para criança, eles fogem do estereótipo da música comercial para consumo fácil tão disseminada pela programação televisiva infantil e pelo merchandising dos subprodutos de seus apresentadores. Paulo Tatit e Sandra Peres cantam e encantam as crianças. Eles mostram a força da inovação criativa e da cultura popular por meio das músicas infantis.

Por Roseli Fígaro

C \& E: Como começou o trabalho musical? Como vocês se juntaram?

Paulo Tatit: Eu trabalhava com música e a Sandra também. Éramos sócios antes da Palavra Cantada. Esse foi o nome que demos ao nosso trabalho infantil. Nosso estúdio chamava-se Salamandra. Fazíamos trilha sonora para teatro, rádio (radionovela), documentários e comerciais. Era um pequeno estúdio de produção. Temos essa sociedade desde 1989.

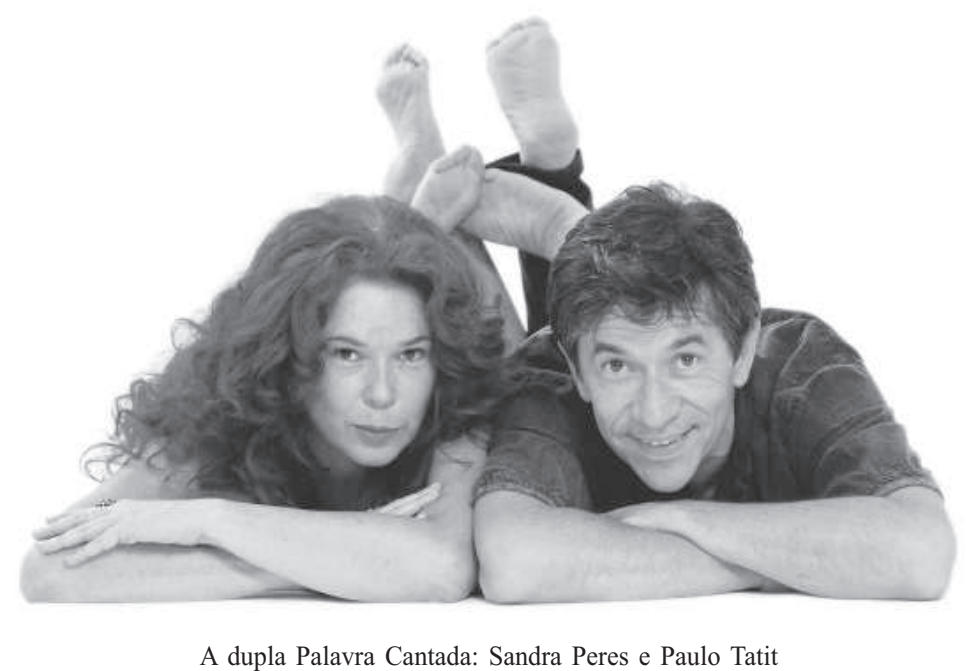

C \& E: Você é músico?

Paulo Tatit: Eu sou músico e a Sandra também. A Palavra Cantada surgiu só em 1994, e por acaso. Foi uma conversa que tivemos logo no mês de janeiro; 
depois, cada um teve uma experiência de férias. Quando nos reencontramos para retomar o trabalho, falamos sobre a mesma experiência que tivemos de questionar como a música infantil, produzida no país, estava fraca. Músico, você sabe, conversa sobre tudo. Então "pintou" essa conversa e, a partir dela, o desejo de fazermos um CD infantil. Pensamos no tema de canções de ninar porque era, do segmento infantil, o que menos havia de novidade; não se tinha praticamente criação. Fizemos o primeiro CD da Palavra Cantada, Canções de ninar ${ }^{1}$. Escolhemos esse nome bem genérico porque não havia quase nada no gênero, e o título já dizia tudo. Nesse $\mathrm{CD}$, atuamos como músicos e produtores. Convidamos vários amigos músicos para fazê-lo conosco. Por exemplo, Arnaldo Antunes, Ná Ozzetti, José Miguel Wisnik; meu irmão, Luiz Tatit, preferiu só fazer letras; meu outro irmão, Zé Tatit, revelou-se um excelente letrista; Edith Derdyk também fez letras muito boas, além de outros amigos que colaboraram. Nossa idéia era um CD com canções de ninar inéditas. Quando o lançamos, não sabíamos o que iria ocorrer. E aconteceu que Canções de ninar teve uma receptividade boa da imprensa: saímos em página inteira de revista, com telefone do estúdio e tudo o mais, porque era um disco independente. $\mathrm{O}$ trabalho contrastou muito com o que havia naquele momento para crianças. Na época, 1994, era só Xuxa e Eliana. Canções de ninar logo foi comparado com as produções dos anos de 1970, como A arca de Noé ${ }^{2}$, de Vinícius de Moraes, e Os saltimbancos ${ }^{3}$, de Chico Buarque de Holanda. Ficamos muito satisfeitos com esse reconhecimento.

C \& E: É mais fácil fazer música para criança?

Paulo Tatit: Não. A dificuldade é a mesma. A música é sempre uma melodia com uma letra, um arranjo, uma interpretação. Tudo isso tem que dar certo para que o resultado seja legal. A música da Palavra Cantada, desde Canções de ninar, sempre foi imaginada para uma criança com um adulto ouvindo junto. $\mathrm{O}$ que é natural, pois em canções de ninar você imagina um adulto ninando. Isso também serviu de modelo para os outros CDs. Passamos a imaginar que nossa música seria sempre para um adulto que está com a criança. Deu muito certo porque elevou o padrão das músicas. Só de pensarmos em um educador, um

1. PALAVRA CANTADA. Canções de ninar. Produzido por: Sandra Peres e Paulo Tatit. 1994. 1 CD.

2. TOQUINHO; MORAIS, Vinícius de. A arca de Noé. Rio de Janeiro: Polygram, 1980. vols. 1 e 2. 2 CDs.

3. BUARQUE, Chico. Os saltimbancos. Rio de Janeiro: Polygram, 1977. 1 disco sonoro.

4. PALAVRA CANTADA. Canções de brincar. Produzido por: Sandra Peres e Paulo Tatit. São Paulo: Velas, 1996. $1 \mathrm{CD}$. pai ou uma mãe cantando junto, é diferente. Não é um disco que o adulto põe para a criança ouvir sozinha, porque a música chega a perturbá-lo, com aquela gritaria, um negócio sempre muito mal produzido, mal cantado, um tema chato.

C \& E: Que tipo de receptividade esse primeiro trabalho obteve das crianças?

Paulo Tatit: Tivemos grande receptividade do público e da crítica. A crítica foi superboa. Recebemos muitos relatos de mães e pais sobre como haviam gostado do CD. Isso foi um estímulo tão forte que resolvemos continuar a coleção, e fizemos Canções de brincar $^{4}$, em 1996.

C \& E: Brincar e cantar são coisas semelhantes?

Paulo Tatit: Existe um tipo de brincadeira, que é a de roda. Nela, o gesto, a movimentação e o canto são uma coisa só. Podemos falar de cantigas de roda 
folclóricas, para exemplificar. Elas ficam incompletas se você não conhecer a brincadeira. Ficar cinco minutos cantando o mesmo verso só tem sentido se a canção for parte da brincadeira. Então, nesse sentido, cantar e brincar são coisas semelhantes. Mas o nosso modo de fazer músicas é uma atividade um pouco diferente. Elas mexem com uma região diferente do espírito da pessoa. As sensações são mais abstratas, mais subjetivas. A brincadeira é um jogo. Ela tem regras e a criança vai achar um meio de resolver o jogo, uma coisa bem cerebral. Às vezes a brincadeira é um teatrinho, uma fantasia que a criança tem com a boneca; uma historinha como uma reprodução do mundo. A criança imita o pai e a mãe, brinca de fazer compra, de andar de automóvel, de ninar boneca etc. Já a música é mais ligada ao artístico do ser humano; trata de aspectos mais subjetivos; é mais espiritual, coisa que todas as culturas desenvolveram, do seu jeito, para fazer ritual ou para conseguir alguma coisa, mas sempre do ponto de vista espiritual.

C \& E: A criança tem esse tipo de percepção? Quer dizer, ela desenvolve esse trabalho mais subjetivo?

Paulo Tatit: Acho que sim. A criança usa a música para isso. Ela faz ritual com a música. Quando pede para repetir a música todo dia e, às vezes, várias vezes no mesmo dia, ela realiza um ritual. Isso vai formando o gosto, o caráter dela. É o que vai curtir depois na vida. Acho que é assim com a música.

C \& E: A opção por música de melhor qualidade faz a criança ter melhor formação? Que papel esse tipo de trabalho que vocês desenvolvem tem na formação da criança? Paulo Tatit: Com certeza forma-se uma pessoa com mais critério, pelo menos na escolha musical. A Palavra Cantada nasceu em 1994. Hoje já temos jovens de 15, 16 ou 17 anos, que ouviam muito nossas músicas quando tinham 5 ou 6 anos e, pelo menos os que eu conheço, são pessoas que têm uma formação musical legal. Por exemplo, minha formação musical, por um motivo ou por outro, deu-se escutando Chico, Caetano, Gil, Milton, Elis, o que chamamos de primeiro time. Então, quero que essas crianças, para quem cantamos, recebam um padrão musical que faça com que elas, no futuro, saibam curtir o que existe

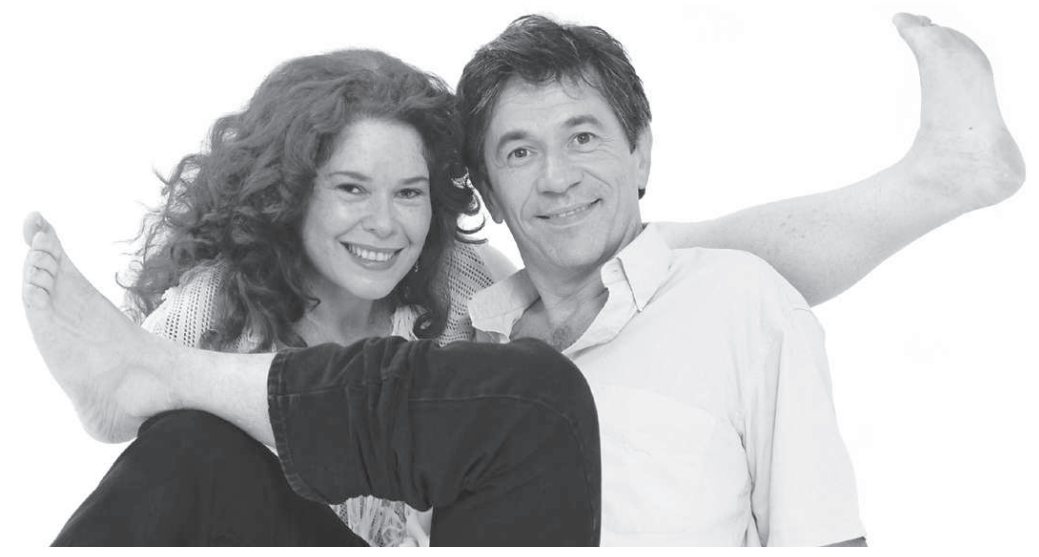

Palavra Cantada: papel importante na formação musical das crianças há mais de dez anos. 
de melhor. É nesse sentido que nosso trabalho vem contribuir. Por exemplo, uma criança de classe média ou de classe média alta tem acesso a um monte de coisas; uma parte, pelo menos, curte coisa boa. Mas o legal é que nossos discos entraram na rede pública de ensino e tivemos uma experiência muito prolongada, muito profunda de tocar nos teatros dos CEUs (Centros de Educação Unificada da Prefeitura de São Paulo), na periferia de São Paulo. Tivemos contato com crianças muito pobres.

C \& E: E o retorno?

Paulo Tatit: O retorno foi maravilhoso porque elas já conheciam alguma coisa do nosso trabalho. Em 2000, a Prefeitura comprou e distribuiu nossos CDs em todas as creches. A Prefeitura de São Paulo, não só a do PT, antes mesmo, já tinha uma tradição de querer educar bem. Aí veio a gestão do PT e fez o maior esforço no sentido de colocar a educação realmente em primeiro plano. Uma prova é ter feito 21 escolas maravilhosas como são os CEUs. Então, a Prefeitura comprou os CDs da Palavra Cantada e distribuiu para as creches e as escolas de primeiro grau, até 9 ou 10 anos. Nossa música foi se espalhando. Quando fomos tocar, em 2003, as crianças já cantavam algumas músicas com a gente. A TV Cultura também passou alguns clipes, com três ou quatro músicas nossas; essas, então, eram conhecidas em detalhes pelas crianças; sabiam a letra do começo ao fim. Percebemos que aquelas crianças de bairros pobres já sabiam que aquela música que estavam ouvindo era uma oferta diferenciada.

C \& E: Elas já estavam conseguindo comparar e fazer distinção, percebendo o que era uma boa música? É isso?

Paulo Tatit: Sim. Existia, via educador talvez, uma crítica e uma escolha, uma opção. Percebíamos isso claramente.

C \& E: Por que um selo independente? Será que se vocês estivessem em uma grande gravadora o sucesso de público não seria maior?

Paulo Tatit: Venho de uma tradição de ser independente. Toquei no grupo Rumo, que sempre foi independente, sempre fez o que quis, na hora que quis, do jeito que quis. Quando criamos Canções de ninar, nem passou pela nossa cabeça procurar uma outra gravadora. Depois apareceu uma grande gravadora querendo distribuir nosso CD. Não aceitamos porque Canções de ninar pode ser mantido em catálogo por muitos anos, duas ou três décadas. Para que fazermos um negócio com uma gravadora que está sempre pensando em números em curto prazo? Tudo bem, ela se empenha, faz uma propaganda, vende dez mil, 20 mil CDs, depois tira de catálogo, e você fica sem seu trabalho. Eu prefiro vender devagar e sempre, e ter o prazer de manter todos os discos que quisermos em catálogo. Ser independente é melhor para gerenciar nossa produção.

Sandra Peres: Gerenciar melhor a produção e, segundo Lenine, os independentes são os mais dependentes, de tudo, como ele.

Paulo Tatit: O artista depende de algumas coisas e independe de outras. Pelo menos para produzir discos, mandar a fábrica fazer e distribuir, somos indepen- 
dentes, que é o que interessa. Dependemos de dinheiro, todo mundo depende dele na verdade, mas temos essa escolha artística de mandar fazer, de mandar fabricar, de pôr em catálogo, de realizar a ação que quisermos com o CD.

C \& E: E para escolher repertório?

Paulo Tatit: É, também para escolher repertório. Sabe em que uma gravadora ajuda muito? A colocar nas rádios e na televisão. Em rádio, principalmente. Ajuda não, ela vai lá e paga...

C \& E: Como é que se chama isso mesmo?

Paulo Tatit: Jabá. O famoso jabaculê, que foi simplificado para jabá. A gravadora paga o espaço e põe o artista na mídia, faz um trabalho. Eles fazem um trabalho que dura dois ou três anos e acaba.

Sandra Peres: Mas a gravadora também nos ajuda, dando uma segurada em parte do show. Porque é o que falta para nós, pois o show tem um custo alto. Um bom show, com recursos, precisa de dinheiro; só a bilheteria não paga. Se o artista tem a gravadora, que entra com um investimento, somado com a verba de bilheteria, ele consegue viabilizar seu trabalho. Seria o patrocinador, no nosso caso.

C \& E: Por que a música da Palavra Cantada não toca nas rádios? Vocês acham que um dos fatores seria a falta de uma grande gravadora?

Sandra Peres: Não é o único fator. Um dos fatores é não ter como comprar esse espaço na mídia. Mas tem um outro, que é o gênero: música infantil não toca nas rádios. Na televisão, é preciso criar um suporte para essa música entrar. A música infantil tem de estar dentro de uma programação. Agora, como é que vamos conseguir colocar para tocar nas rádios nossa música dirigida às crianças?

Paulo Tatit: Bom, talvez possa melhorar, porque fomos convidados a fazer um programa infantil para a rádio Eldorado, que já vamos começar a gravar.

C \& E: Que maravilha, que boa notícia!

Paulo Tatit: O programa será aos domingos. Com ele vamos conseguir mostrar melhor nosso trabalho. De repente está acontecendo essa mudança e a Palavra Cantada é uma das responsáveis por ela, ou seja, de as pessoas entenderem que a música infantil não é isolada, só para a criança. Nossa música é para o adulto curtir com a criança. Acho que nossos shows também têm ajudado. Porque, além de ter feito essa coleção, eu e a Sandra inventamos uma coisa óbvia: fazer show de música para criança. Existe teatro para criança, espetáculo de circo, teatrinho, grandes produções e tal. Mas pegar os instrumentos e ir para o palco com som e luz e fazer show para criança, isso é novo, e nós fazemos isso. Quando começamos com os shows, levávamos alguns adereços. Depois resolvemos tirar todas essas coisas: as máscaras, os chapéus, o cenário, tudo. Vamos fazer um show de música! E tudo que quisermos mostrar virá dos instrumentos. Quer dizer, o músico que está atrás pode vir tocar na frente, para a criança ver. Tudo de 
lúdico que quisermos provocar, iremos tirar dos instrumentos. A criança gosta de ouvir e gosta de cantar. A premissa é a seguinte: não precisamos de enfeite, não precisamos ter um subterfúgio para conquistar a criança. Vamos olho no olho e confiamos na música. Passamos a fazer esses shows estritamente musicais e a família inteira tem ido. Nunca vai criança sozinha, mas sempre com o pai e a mãe. Ouvir música infantil é um programa familiar.

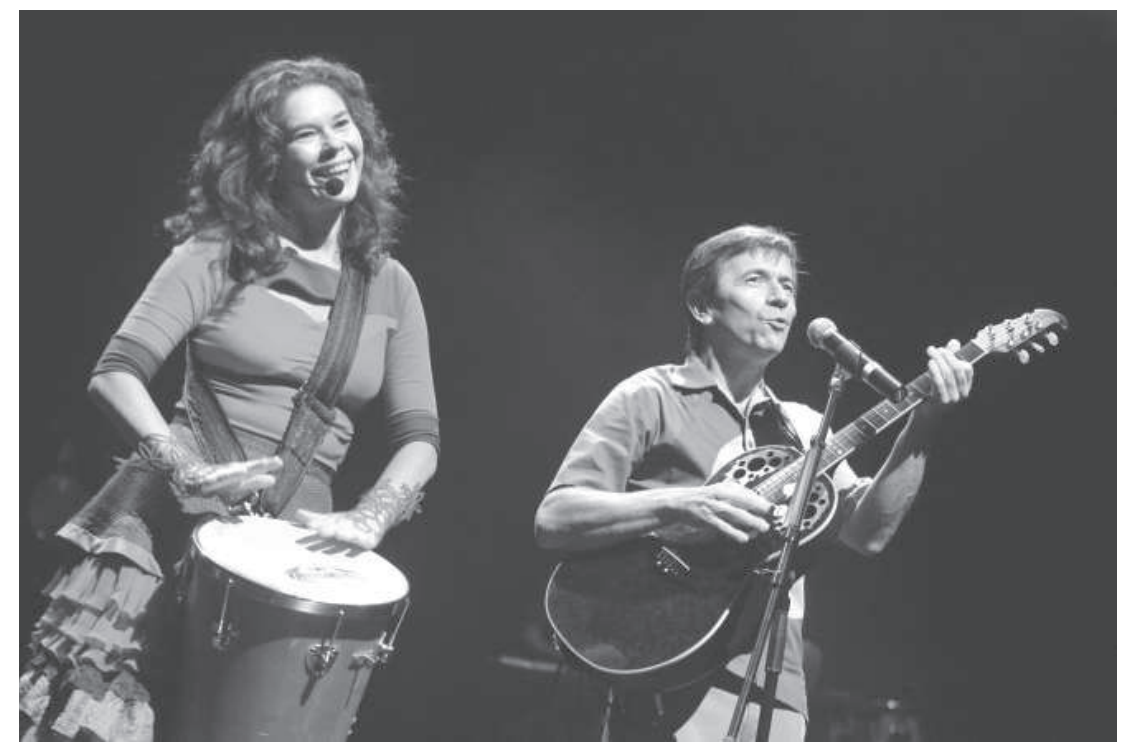

Sandra e Paulo: show para crianças e adultos.

Sandra Peres: É um programa que os pais gostam de fazer com os filhos. E é legal o pai e a mãe irem, porque eles também querem curtir a música. Esse é o diferencial da Palavra Cantada.

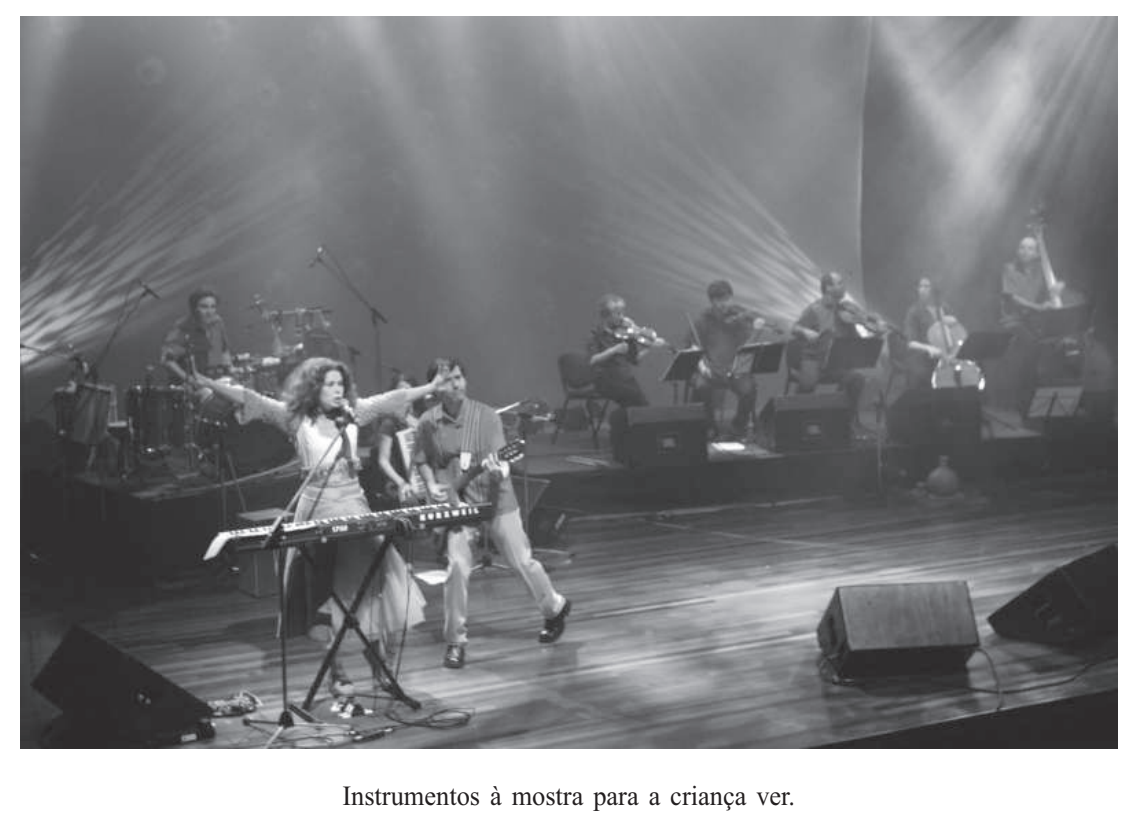


C \& E: Como surgiu a idéia e qual o conceito que orientou a realização do CD Canções do Brasil?

Sandra Peres: O conceito nasceu da nossa vontade de saber o que as crianças brasileiras estavam cantando, além do que elas ouvem no rádio e na televisão, é claro.

Paulo Tatit: Queríamos saber se existia música com vínculo regional, se isso ainda persistia mesmo com todo o poder do rádio e da TV.

Sandra Peres: A idéia foi irmos para os lugares ouvir as crianças cantarem. Houve uma pré-pesquisa de dois etnomusicólogos que fizeram um mapeamento para nós. E então, íamos para onde já sabíamos mais ou menos o que poderia acontecer. Tínhamos indicações de alguns grupos, de algumas crianças, o que elas costumavam exercitar etc. O objetivo desse trabalho foi saber o que as crianças estavam gostando de cantar e de tocar.

Paulo Tatit: Você perguntou por que executamos essa idéia; bom, há os motivos internos também. Fizemos o Canções curiosas ${ }^{5}$, nosso quarto $\mathrm{CD}$, e ficamos muito satisfeitos com ele. Foi daí que surgiu essa idéia de realizar uma coisa bem diferente. Pensamos em dar uma reciclada no nosso próprio background musical, e deu muito certo sairmos para conhecer as coisas que as crianças estavam cantando fora de São Paulo. Em 1997, começamos a trabalhar Canções do Brasil ${ }^{6}$, já com esse nome. Paralelamente, uma turma do Rio de Janeiro estava trabalhando outro $\mathrm{CD}$, chamado Músicas do Brasil ${ }^{7}$, do antropólogo Hermano Vianna. A diferença é que pesquisávamos músicas do ponto de vista das crianças. Eu não sei qual era a realidade deles, mas nós nos contentamos com uma boa música de cada estado brasileiro e nosso CD tem 26 músicas. Se fôssemos pesquisadores, teríamos que fazer um trabalho mais aprofundado. Mas não tínhamos esse compromisso. Queríamos uma música boa por estado. Daí, fizemos uma seleção bem bacana. Acho que pegamos uma fase em que os artistas estavam voltando a pensar o Brasil. Coincidiu com o trabalho de vários artistas que traziam o tema da regionalização: Lenine, Chico Science, Zeca Baleiro, uma gama de gente assim.

Sandra Peres: A diferença entre Canções do Brasil e Músicas do Brasil é que não queríamos um disco de pesquisa. Queríamos que as crianças se apropriassem da música como cantores, como músicos, como compositores. E de fato conseguimos mostrar que elas já tinham se apropriado das músicas no dia-a-dia da vida delas, e já estavam, de alguma maneira, reciclando aquela música regional. Fomos fazendo arranjos diferentes, colocando um ou outro instrumento que não existia naquela manifestação. Queríamos que a criança urbana daqui de São Paulo, ou de outra cidade brasileira, ouvisse Canções do Brasil e não tivesse a impressão de estar escutando músicas que pararam no tempo, como se fossem de museu. O resultado foi tão bem-sucedido que, por exemplo, a música Sai, preguiça, que é um forrozinho, pode ser cantada em qualquer lugar.

Paulo Tatit: Queríamos que as crianças se encantassem com as músicas umas das outras.
5. Id. Canções curiosas. Coleção Palavra Cantada. 1998. 1 CD.

6. Id. Canções do Brasil. Coleção Palavra Cantada. 2001. 1 CD.

7. VIANNA, Hermano. Projeto Músicas do Brasil. São Paulo: Abril Music, 2000. 4 CDs. 
C \& E: A idéia de trabalhar as culturas tradicionais e as culturas regionais não no sentido de resgate?

Paulo Tatit: Isso mesmo. Nossa idéia foi mostrar quão viva estão as músicas regionais. Quão viva estão essas manifestações fora dos grandes centros urbanos.

C \& E: É um paradoxo? Acabamos de falar da força dos meios de comunicação e dessa música que não tem tanta qualidade e está sendo tocada para a criançada. E vocês encontraram as crianças cantando músicas que estão fora do circuito comercial. Como é isso do ponto de vista do mercado?

Sandra Peres: O artista não pensa muito sobre a tendência do mercado. Pelo menos nós não pensamos. $\mathrm{O}$ artista tem a missão de se relacionar através da intuição, do que ele sente que pode ser melhor. Acho que o artista que pensa: "Vou fazer isso porque é melhor para o negócio" não dá certo. Em geral, quem pensa se vai pegar ou não é a gravadora.

Paulo Tatit: $\mathrm{O}$ interesse pela música regional aconteceu por causa da globalização, que deu mais força para as manifestações musicais regionais. Por um lado, a cultura dos países ficou mais forte. No mundo globalizado, o outro só vai se interessar pelo que você tem de específico. Digamos que haja aquela coisa que se chama universal, que é a música americanizada. A música universal é a americana, em inglês. Por quê? Porque o mercado deles é universal. Eles não têm o menor interesse em ouvir um rock produzido aqui no Brasil. Eles têm interesse de ouvir outra coisa. Daí começa a se valorizar o que se tem de específico. Quando se pensa em Brasil, também vemos o músico urbano de São Paulo ou do Rio de Janeiro querendo ver o que tem de específico nos demais estados. Se viajássemos para o meio do sertão e encontrássemos um cara que faz uma imitação de um rock urbano, ficaríamos decepcionados. Valorizaríamos muito mais um tipo de percussão que só ele sabe fazer, um instrumento que só ele fabrica, que tem na região dele etc.

C \& E: Vocês sentiram isso nas crianças?

Paulo Tatit: Ah sim, só gravamos músicas que elas sabiam de cor e salteado. Nunca deu certo e não foi para o disco nenhuma música que as crianças estivessem lendo. A música deveria estar totalmente incorporada por elas.

Sandra Peres: Tanto que tínhamos de pedir para as crianças pararem de dançar e brincar, para que pudéssemos gravar, o que era dificílimo para elas. Gravamos tudo no lugar onde elas se reuniam. Em geral, elas usavam sandálias havaianas e batiam os pés no chão. Lembro do som da batida, aquela coisa da borracha no chão, o arrastar das sandálias na poeira, na terra. E tivemos até que pedir para elas cantarem sem dançar.

C \& E: Como vocês conseguiram encontrar a música regional sendo cantada pelas crianças?

Paulo Tatit: Elas cantam de tudo. Um terço das crianças que participaram das gravações ensaia aos finais de semana. São grupos grandes, que ensaiam, por 
exemplo, maracatu, bumba-meu-boi, boi-bumbá, congo, aqueles coros que se vê em Parintins. Elas ensaiam mesmo, ficam tocando e cantando o dia inteiro. Até podem estar massacradas por outras músicas, mas têm esse repertório a mais do que nossas crianças de classe média, que vivem nos centros urbanos. Elas têm o repertório de rádio, de televisão, da propaganda, mas também o outro repertório do seu grupo cultural. O repertório das crianças urbanas é o repertório de televisão, de rádio, e não tem outro, a não ser que o pai e a mãe tenham uma ótima discoteca em casa, e que ouçam muito um tipo de música diferente, o que é raro.

C \& E: Vocês acham que a sociabilidade do grupo é que renova a relação das crianças com as músicas? Os meios de comunicação não nos proporcionam essa experiência? Paulo Tatit: Não sai disso, sem dúvida. Porque essas músicas que gravamos, muitas delas, foram criadas, melodias e letras, ao batuque do maracatu ou da congada, mas foram criadas, por exemplo, recentemente. São músicas dinâmicas; não estão passadas. Algumas poucas são passadas porque não conseguimos, em todos os estados, achar uma experiência mais dinâmica. Veja o Pedrinho do Cavaco, do Rio de Janeiro, por exemplo. Foram os compositores de sua cidade que fizeram uma música especial para ele. Outro exemplo é a Angelina, a menina do Mato Grosso do Sul, que toca violão e que canta muito bem. Ela também cantou uma música de um compositor contemporâneo, Paulinho Simões; ele e outros parceiros fizeram a música Quero quero. Angelina canta essa música altamente regionalizada, só que na voz dela, de uma criança de 9 anos, com uma pegada de violão que só tem ali naquele lugar. Então, existe esse ambiente criativo de novas coisas regionalizadas, que a criança em geral vai aprendendo. Na cultura popular, pessoas de todas as idades participam dos rituais, dos encontros: os velhos, os jovens e as criancinhas. Como, por exemplo, na capoeira, que tem canto, dança, aprendizado, ritual, regras, disciplina, e todas as idades participam.

Sandra Peres: Separar criança de adulto no momento de lazer é costume urbano. Qualquer índio, qualquer grupo de maracatu, qualquer igreja católica, quando reúne, é todo mundo junto, brincando e conversando.

C \& E: Então poderíamos dizer que qualquer tema serve para música infantil?

Paulo Tatit: Qualquer tema, não. Os temas de amor ficam de fora, porque as crianças não têm idade ainda. É um grande tema para música adulta, mas para elas é melhor outro.

Sandra Peres: Os temas lúdicos, de observação da natureza, de brincadeira com palavras, os temas que falam de coisas do cotidiano delas, dos bichos, das histórias (músicas que contam histórias). Mas, realmente, música de amor, acho que não. Outro tema que não é bom é aquele que quer ensinar coisas...

Paulo Tatit: Música didática, no sentido de ensinar uma coisa objetiva. Isso me irrita muito. Quando o adulto vai fazer música de criança para ensinar sobre o trânsito, a escovar os dentes... ou mesmo sobre a natureza e o meio ambiente. Isso tira a alma da música. Música é uma coisa que não é para ser tratada 
objetivamente. É mais poesia, humor, humor poético; é mais subjetiva e espiritualizada. As músicas que concretizam são como o próprio cotidiano.

Sandra Peres: O que pressupõe uma atitude até antipática para com os educadores e pais. Se você não consegue fazer seu filho aprender a escovar os dentes, e o professor precisa pôr uma musiquinha para não sei o quê... Isso é sinal de algum problema.

C \& E: Vocês não trabalham com intenção didática, no sentido da educação?

Sandra Peres: Temos duas músicas sobre a água, por exemplo. Uma delas está no Canções de ninar e fala do ciclo da água: "da nuvem até o chão, do chão até o ralo", enfim... Mas não tem nada de didático, de científico. Há uma outra no Canções do Brasil, que é a do arco-íris que bebe água no mar e quando ele quer despejar, despeja por cima da serra. Esse é um jeito de inspirar e educa muito mais.

Paulo Tatit: Isso que estamos falando também depende do talento do artista para lidar com a linguagem. Estou me lembrando daquela música do Arnaldo Antunes, Lavar as mãos (mão) ${ }^{8}$, que foi feita para ensinar a lavar as mãos antes de comer. O tratamento é diferenciado; na verdade, não é nem o tema. Vou retirar o que disse. Quanto ao tema, pode ser qualquer um; depende do tratamento que se dá.

Sandra Peres: O tema do amor não pode ser... porque amor é uma coisa que vem depois de uma certa idade.

Paulo Tatit: É, o amor, a dor de cotovelo, a desilusão amorosa, isso é para uma outra faixa etária.

C \& E: Mas e essa história da criançada ter namoradinho na escola, de levar presente no dia dos namorados?

Sandra Peres: Isso é totalmente diferente. Uma coisa é passar por essa fase da vida e viver isso com pureza, com poesia, com aquele frisson que você e eu vivemos; outra coisa é fazer um hino para isso. Mas se você abre essa possibilidade, vem cada coisa... A grande música de sucesso atualmente no nosso país para criança é de amor.

C \& E: Qual é?

Sandra Peres: Quem canta é a Adriana Calcanhotto9. É aquela: "Amor sem beijinho, Buchecha sem Claudinho, sou eu assim sem você". Essa é a música das paradas. É bonita e também foi colocada numa novela. Tem uma exposição que gera esse sucesso. Mas discordo que essa música que faz tanto sucesso seja uma música infantil.

8. ANTUNES, Arnaldo.

Lavar as mãos (mão). In: Castelo Rá-Tim-Bum. São Paulo: Velas, 1995. 1 CD

9. CALCANHOTTO, Adriana. Fico assim sem você. In: Adriana Partimpim. Rio de Janeiro: BMG, 2004. 1 CD.
C \& E: E aquele axé da dança da garrafa?

Sandra Peres: Para a criança brasileira, tudo que for físico, que mexa, que tenha um requebrado chama a atenção e ela vai dançar, e nós também. A diferença entre uma situação e outra é o mediador. $\mathrm{O}$ mediador é o adulto, e o adulto é o grande perversor e o grande transgressor. 
Paulo Tatit: Só que a proposta dessa música que gerou a dança da garrafa não foi dirigida para as crianças. Mas elas ficam expostas e os adultos incentivam.

Sandra Peres: O pai vê e acha engraçadinho; o titio chega e pede para dançar para ele. Depois o que acontece? A menininha de 12 anos - e hoje elas estão superdesenvolvidas; são pequenas deusas, com um corpo maravilhoso - está dançando a garrafinha na frente dos tios... e daqui a pouco aparece o tal do abuso...

Paulo Tatit: $O$ assédio sexual.

Sandra Peres: Claro, sempre aconteceram os assédios de enteados. Uma manifestação apelativa é uma coisa que excita um homem mais velho.

C \& E: E os ritmos do CD Pé com pé? Percebo que vocês estão trabalhando novamente os sons do Brasil, pelos ritmos, pelos instrumentos, pela diversidade de ritmos que vocês conseguem conjugar. É isso mesmo?

Paulo Tatit: Esse é um trabalho pós-Canções do Brasil. Sem dúvida, pensamos em abordar a raiz profunda das músicas. Trabalhamos muito com os percursionistas, com o toque dos músicos em cada instrumento de percussão, e dali fazíamos a música. E também porque queríamos fazer música para dançar. Surgiu a idéia de fazer um disco que fosse uma opção para uma festa, uma coisa mais corporal. Fizemos o Pé na cozinha ${ }^{10}$, que é o segundo $\mathrm{CD}$, espelho do primeiro, Pé com pé ${ }^{11}$, só instrumental. Tínhamos vontade de fornecer matéria-prima para os coreógrafos montarem uma trilha de dança.

Sandra Peres: Foi inspirado no Canções do Brasil.

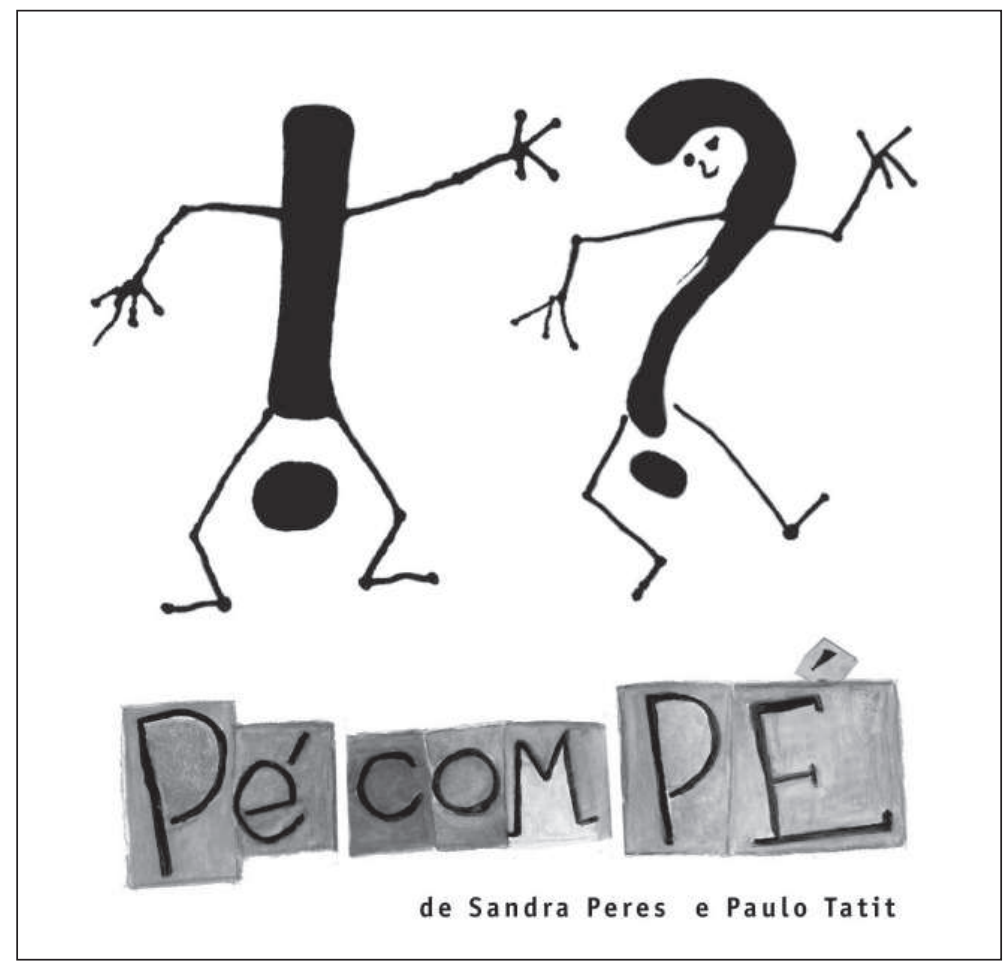

Música instrumental com muita percussão no CD Pé com pé.

10. PALAVRA CANTADA. Pé na cozinha. Produzido por: Sandra Peres e Paulo Tatit. 2005. 1 CD.

11. Id. Pé com pé. Produzido por: Sandra Peres e Paulo Tatit. 2005. 1 CD. 
C \& E: E os instrumentos? Os arranjos? Como é trabalhar com toda essa diversidade? Sandra Peres: Foi uma opção nossa. Somos muito ambiciosos. Pode ser um violão e uma voz, mas tem que ser o violão e a voz. Gostamos de colocar idéias inovadoras em prática. Inovadoras no campo infantil.

Paulo Tatit: Experimentamos bastante.

C \& E: Com as crianças é possível inovar mais pois elas não têm estereótipos?

Sandra Peres: Quem faz a criança adquirir o estereótipo é o marketing das indústrias. A menina vai usar batom, passar esmalte com 9 ou 10 anos. Hoje tem o esmalte para a menina, então ela adquire esse comportamento de mulher. As crianças cantam e dançam imitando um certo comportamento sensual do adulto, porque é bacana imitar o artista. O veículo de comunicação potencializa isso, e a indústria do marketing vende qualquer coisa.

Paulo Tatit: Esses programas infantis de televisão também. Vi um capítulo de O Sítio do Pica Pau Amarelo e nem o reconheci. Anteriormente havia uma proposta legal. Agora já está estereotipado. Assisti a uma cena totalmente adulta: uma menina de, sei lá, 10 ou 11 anos, vira-se para o menino e fala assim: "Me aguarde!". Uma cena totalmente adulta. Imagine uma criança falando "Me aguarde"..., que é uma expressão ligada à vingança, à sedução do outro para pegar um objeto. Isso se parece com a novela das oito. Aliás, as pessoas vêem uma diferença entre a novela mexicana e a da Globo; eu só vejo mudança no penteado.

Sandra Peres: Na roupa também, porque as roupas mexicanas têm mais brilho. E a maquiagem é mais forte...

C \& E: Quais são seus novos projetos?

Paulo Tatit: Um projeto é divulgar nossos antigos trabalhos no Brasil inteiro. Nossa sede fica em São Paulo, onde somos razoavelmente bem conhecidos. Mas saindo um pouquinho daqui fica mais difícil. Temos uma coleção de discos e dois shows, um com nossa banda e outro com uma pequena orquestra. Esses shows são tão ricos, que queremos levá-los aos demais estados.

C \& E: Qual tem sido a repercussão do trabalho de vocês entre os educadores? Paulo Tatit: Ótima. Desde Canções de brincar nosso trabalho tem entrado nas escolas particulares e, um pouco depois, também nas públicas. Para nós, os educadores são um público fundamental. Temos mala-direta especial para eles, damos descontos... Os educadores têm um papel mais forte que os próprios pais em difundir boa música, o conceito de boa música. Os educadores estão mais atentos para a formação intelectual das crianças. Aliás, sou totalmente a favor da educação por educadores. Pai e mãe têm de dar afeto. Os educadores têm várias crianças para educar, então eles sabem colocar limites, coisa que não se tem em famílias ricas, por exemplo. Nas famílias pobres, em crianças mal-educadas a mãe bate, dá tapa... Então, os educadores colocam limites a esses extremos da má-educação. As crianças precisam de limites, aprender a 
respeitar a vez do outro, aprender as regras. Os educadores são os grandes formadores de cidadãos.

C \& E: A música tem lugar na escola?

Paulo Tatit: Sim. Por exemplo, para ouvir no pátio. De maneira mais informal, porque nem toda escola dá formação musical. Desde o berçário, é importantíssimo ouvir música. Não acho ruim a música ficar só na parte do pátio, que é um lugar legal, da brincadeira. Nunca gostei da idéia de música dentro da sala de aula, porque não tem muito o que fazer, aquelas carteiras prendem as crianças. Para mim, música é no espaço lúdico do pátio, fora da sala. É importante fazer uma atividade escutando música, cantando música, o professor fazer uma roda, ficar cantando com as crianças. Não há recursos na escola, instrumentos, mas mesmo assim dá para cantar. Cantar é ótimo: cantar sozinho, cantar em dupla, cantar em trio, não só ficar cantando todo mundo junto.

C \& E: Ou seja, apesar de tudo, dá para trabalhar com a música na escola?

Paulo Tatit: Sim. Isso posso dizer, porque tenho CDs de outros países, da Índia, da China e da África, que são os que mais gosto. Tenho os da Europa também, são muito legais. Da Bulgária, por exemplo, é sofisticado, as crianças cantando na escola. Elas estão cantando muito bem nesses países. Da África, tenho trabalhos do Senegal e de Camarões. O CD das crianças de Camarões é lindo, elas cantam muito bem. As crianças da China cantando são maravilhosas... é um arraso total; as da Índia também. As crianças cantam com energia, com vontade. Até perguntei para o Paulo Dias, nosso orientador nessas pesquisas todas, o porquê dessa diferença: nossas crianças não cantam bem como as outras, e o nosso país é muito musical. Paulo Dias disse-me que é questão de tempo; essas culturas são muito mais antigas que a nossa. Estamos falando de quinhentos anos de história, enquanto eles têm cinco mil anos, e isso faz toda a diferença nessa hora.

C \& E: A escola, em geral, tem sido tratada e interpretada, tanto por educadores quanto pelos pais e estudantes, como um lugar de trabalho, de sofrimento, como um mal necessário. Você acha que a música pode ajudar a mudar essa idéia?

Paulo Tatit: Pode sim. A música salvou a mim e a alguns amigos meus. Fazíamos música no ginásio. Com 11 anos, ganhei um violão e, na escola, tinha aquela meia dúzia que gostava de música. Eu estava aprendendo violão e uns tocavam teclado e, ao nosso entorno, ficava uma porção de gente cantando. Mas isso fora da aula, porque a aula de música era objeto de chacota. Não tinha nada a ver com a música que fazíamos. Formamos um grupinho, uma bandinha e tocávamos nos horários livres. A escola não aproveitava isso, os professores nem reparavam. Tocávamos o tempo todo no recreio, chegávamos antes, ficávamos depois, íamos aos sábados e aquela energia era totalmente desprezada pela escola. A escola não enxergava que poderíamos ser músicos. $\mathrm{Na}$ minha época, a escola não via aquilo como uma profissão. Aliás, uma profissão muito boa. 
Resumo: A dupla Paulo Tatit e Sandra Peres, da Palavra Cantada, soma dez anos de carreira e a conquista de um espaço para a música infantil de qualidade, consolidada por um selo independente e com um portfólio composto de clássicos como Canções de ninar, Canções de brincar, Cantigas de roda, Canções curiosas, Meu neném, Canções do Brasil, Pé com pé, entre outros. Paulo Tatit e Sandra Peres cantam e encantam as crianças ao mostrarem a força da inovação criativa e da cultura popular em músicas infantis. Eles comentam também a opção pela independência na indústria fonográfica e a relação desejada entre a produção artística e a divulgação da obra. Falam, ainda, como as escolas podem construir uma relação diferente com a música para ampliar o conhecimento e a cultura de seus alunos.

Palavras-chave: música infantil, qualidade, produção artística, escola.
Abstract: Paulo Tatit and Sandra Peres form Palavra Cantada duo, which has ten years on the road. They present infantile quality music, recorded in an independent way and several classics, such as Canções de ninar, Canções de brincar, Cantigas de roda, Canções curiosas, Meu neném, Canções do Brasil, Pé com pé, among others. Paulo Tatit and Sandra Peres sing and enchant children due to the power of critical innovation and popular culture in their compositions. They also comment on their option of being independent in phonographic industry and the aimed relation between artistic production and diffusion. According to them, school should establish a different relation with music in order to increase their students' knowledge and culture.

Keywords: infantile music, quality, artistic production, school. 